\title{
THE STRUCTURE AND CONTENT OF THE SYSTEM FOR THE FORMATION OF COMMUNICATIVE COMPETENCIES OF FUTURE TEACHERS
}

\section{Salohiddin Turdimurodovich Alikulov}

Head Of "Professional Education" Department Of Jizzakh Polytechnic Institute, Associate Professor, Jizzakh Region, Jizzakh City, Uzbekistan

Obid Ergashjanovich Azizov

Jizzakh Polytechnic Institute, Base Doctoral Student Of The Department Of "Professional Education" Jizzakh Region, Jizzakh City, Uzbekistan

\section{ABSTRACT}

The main goal of the article is to form and develop the communicative competencies of future teachers by connecting them with the important rules of communication and speech activities. The article also describes the types of communicative speech activities, the conditions for their development.

KEYWORDS:- Communicative competence, gnostic, axiological, interactive, empirical, communication motives, tutor, dispute, discussion, emotional infection, pedagogical coaching.

\section{INTRODUCTION}

Comprehensive reforms in the education system of the country are aimed at ensuring a high level of quality of education, one of the key factors of success in this area is the development of communicative competence of future teachers, acquisition of modern knowledge, skills and research based on innovative approaches to education. . This, in turn, requires a radical reform of the education system, as a perfect education system plays an important role in educating students to be creative, independent, communicative competencies on the basis of an innovative approach, which determines the future intellectual potential and development of the republic.

\section{Main PART}

We consider the features of the organization of the educational process in the formation of communicative competence in students of future teachers.

The universal structure of competence has been defined as a set of gnostic, axiological, interactive, and empirical components that explain each other and the units of their content based on the requirements of college students.

The units of content of the gnostic component in 
CURRENT RESEARCH JOURNAL OF PEDAGOGICS 2(6): 141-151, June

2021 DOI: https://doi.org/10.37547/pedagogics-crjp-02-06-27

ISSN 2767-3278

(C)2021 Master Journals

\section{Crossref dof 81 Google}

Accepted 25th June, 2021 \& Published 30 $0^{\text {th }}$ June, 2021

accordance with the requirements of the knowledge of future teachers are ageappropriate, oral and written, direct and indirect, perceptions of the types and methods of communication in the native language and foreign languages.

The formation of personal outcomes defines the content units of the axiological component, which is represented by a set of possible goals of communication, such as students' emotional selfexpression, presentation, information request, information exchange, belief, reasonable rejection [1].

Professor N.Muslimov defines communicative competence as the ability to communicate sincerely with all participants in the educational process, including students, to listen to them, to have a positive impact on them, highlighting the essence of the qualities reflected on the basis of professional competence.

I. T. Aliev defines communicative competence as the ability to set and solve certain types of communication tasks: goal setting communication, situation assessment, consideration partner intentions and communication methods (partners), selection of adequate strategies, assessment of communication success, self-speech behavior readiness to change their actions [2].

Defines the requirements for of future teachers to master universal communicative movements. They, in turn, develop students 'communicative behaviors and appropriate oral and written communication skills in monologue, dialogue, polylogue, comment, message, speech, question, rebuttal, telephone conversation, argumentation, debate, debate; b) letter, telegram, SMS) defines the units of content of the interactive component of communicative competence, which involves the formation.

The interdependence and systematization of the achievement of the planned results in the form of communicative competence of is significantly determined by the possibility of the results obtained and the general goals and the appropriate ratio of tasks for their formation. This situation explains the existence of an empirical component of students 'communicative competence, which involves the result of communication based on process reflection and control of its content. It can be seen that the formation of each component has certain purposeful, semantic and didactic features related to the application of methods, techniques and tools and the achievement of the results of the formation.

From the above arises the following pedagogical conditions for the organization of the logical educational process, namely the interdependence of solving the problems of forming the components of communicative competence of students of future teachers. These tasks are determined by the structure of communicative competence. The formation of each of the components - gnostic, axiological, interactive and empirical - has a separate task [3]:

- The formation of the gnostic component of communicative competence (knowledge of future teachers about the types and methods of communication);

- Formation of the axiological component of communicative competence (communication motives and goals);

- Formation of an interactive component of communicative competence (universal communicative actions and appropriate oral and written methods of communication: a) monologue, dialogue, polylogue, reflection, message, speech, question, denial, telephone conversation, argumentation, discussion, dispute; b) letter, telegram, SMS); 
CURRENT RESEARCH JOURNAL OF PEDAGOGICS 2(6): 141-151, June

2021 DOI: https://doi.org/10.37547/pedagogics-crjp-02-06-27

ISSN 2767-3278

(C)2021 Master Journals

\section{Crossref dof 81 Google}

Accepted 25th June, 2021 \& Published $30^{\text {th }}$ June, 2021

- Formation of the empirical component of communicative competence (reflection of the process and results of communication on the basis of control of its content, methods and means of interaction;

Another pedagogical condition for the organization of the educational process on the formation of communicative competence is the various forms of organization of this process.

Course, as always, is the main form of organization of education (teaching) in college. Traditional lesson signs are strictly regulated (subordinate) stages; self-determination of lesson objectives by the teacher; planning of interaction methods, appointment of a partner in the activity and subjective assessment of the results of this activity are also carried out by the teacher; the whole communication is based (consists) mainly on the monologue of the teacher or students. Such a course is not in line with the updated educational content and the formation of communicative competence of future teachers [4].

The leading requirement for a modern lesson is that students have communicative activity. It is in the group, in pairs, that the teacher and the students interact at the same time on different topics are the hallmarks of a modern lesson [5]. Classroom communication would not be effective if it was planned in advance with the didactic objectives of the lesson in mind.

In addition, during the lesson should be taken into account the psycho-age and individual characteristics of each student and the whole class, the individuality of the teacher. Teacherled (frontal) work should not be a leader in a modern lesson because it does not allow the set goals to be achieved. The teacher should prefer to work in pairs, in groups and in groups in the classroom.

It is important to keep in mind the following requirements when developing a lesson:

- The defining organizer of the lesson is the didactic purpose;

- Three types of lessons are defined for didactic purposes (study of new material, consolidation of new material, return of the studied material, control lesson, joint (combined, combined) lesson, introductory lesson, generalization lesson);

- The type of course determines its structure;

- At each stage of the lesson should be organized communicative activities of students, which, in turn, will allow to solve the tasks of each stage.

But the teacher, no matter how much he wants to, is not able to take into account the nature of the communicative activity in each lesson and provide the conditions to engage the students in this activity. Because the achievement of subject results is a priority in the course activity [6].

There is another option to organize the learning process - it is extracurricular forms. Extracurricular forms, like lessons, are focused on achieving planned outcomes. If the achievement of subject outcomes is a priority in the course activity, the subject outcomes will be retained in the extracurricular activities, and the individual and meta-subject outcomes will lead.

Extracurricular activities of students of the Pedagogical College are organized in the areas of personal development: sports and health, spiritual and moral, social, intellectual and cultural. The structure of the extracurricular activity and its content may not even roughly remind the lesson. "The methods of student activity here should be fundamentally different from those in the classroom, the teacher plays the role of assistant, organizer, tutor in extracurricular activities. It is important that he helps students: organizational, meaningful and emotional, without which most students will not 
CURRENT RESEARCH JOURNAL OF PEDAGOGICS 2(6): 141-151, June

2021 DOI: https://doi.org/10.37547/pedagogics-crjp-02-06-27

ISSN 2767-3278

(C)2021 Master Journals

\section{Crossref do) 81 Google}

Accepted 25thJune, 2021 \& Published 30 th June, 2021

be able to engage in collaborative activities "[6].

However, the effective formation of communicative competence of future teachers is possible only if they adhere to the pedagogical conditions of the educational process - the choice of forms of organization of the educational process on the basis of differentiated components of students' communicative competence - gnostic, axiological, interactive and empirical.

Thus, lesson forms of organizing the learning process are more effective for shaping the gnostic and interactive components of communicative competence. It is more appropriate to use extracurricular forms to shape the axiological and empirical components of students' communicative competence.

Another important pedagogical condition for the organization of the educational process for the formation of communicative competence is the choice of methods and techniques for the formation of components of communicative competence of future teachers. Methods such as forms of organization of the educational process are determined by the nature of students' communicative activity. The main task of the method is "organization and management (regulation) of activity in any form" [7,404 p.].

The choice of optimal methods of forming the components of communicative competence is made in accordance with the structure of competence and the tasks of its formation, the structure of the components of communicative competence of students - gnostic, axiological, interactive and empirical.

The gnostic component of communicative competence (knowledge of types of communication: native and foreign language, oral and written, direct and indirect, verbal and non-verbal) can be formed using methods such as teacher storytelling, explanation, listening and
Socrates conversation [8].

If the goal is to form an axiological component of communicative competence (students 'communicative goal setting and understanding of meaning), then the following methods are appropriate: dispute, discussion, heuristic and democratic conversation, emotional transmission, belief, pedagogical coaching, and so on.

Methods of forming the interactive component of communicative competence (universal communicative actions and appropriate methods of oral and written communication) include monologue, dialogue, polylogue, message, reflection, debate, discussion, speech, argument, question, denial, letter, telephone conversation, telegram, etc.

The empirical component of communicative competence is formed using methods of organizing communicative activity, such as dispute, discussion, message, abstract, project activity, presentation.

\section{Results AND DISCUSSIONS}

Methods of shaping the axiological component of communicative competence (students' communicative goal setting and understanding of meaning) are less commonly used by educators than traditional methods. That is why they require additional lighting.

Dispute is a method that allows the formation of an axiological component of communicative competence. It is a conflict of ideas. The purpose of this method is to form relationships, feedback, evaluations. Through this method, the student learns to defend their views by proving them, to convince them of other people in modern ways, to reject false views, and not to give up ethical norms and requirements.

Discussion is a method based on the exchange of views on a particular problem $[9,284$ p.]. Debate 
CURRENT RESEARCH JOURNAL OF PEDAGOGICS 2(6): 141-151, June

2021 DOI: https://doi.org/10.37547/pedagogics-crjp-02-06-27

ISSN 2767-3278

(C)2021 Master Journals

\section{Crossref do) 81 Google}

Accepted 25thJune, 2021 \& Published 30 th June, 2021

is the discussion and resolution of contentious issues. In the discussion, the student will have the opportunity to discuss with the teacher and classmates the goals, methods, means of communication as equal partners. A debate arises when a question arises that does not have a single answer (solution). The result of the discussion is usually an agreement, understanding, a new look at the problem, a collaborative decision (solution).

It is very important that the educator organizes the discussion in secret, emphasizes the discussion, strives to take the position of partnership, supports the communicative activity of students on the basis of ensuring their subjective position.

Emotional infection (damage) is a positive mood, the transfer of emotion from teacher to student. These emotions are expressed through channels of communication such as words, intonation, facial expressions, gestures, gaze, speechless sounds, visual images, short written texts. The teacher's benevolent attitude in discussing complex issues, emotional speech helps to create a positive background of trust. Emotional infection can be very strong, but strong emotions need to be reinforced by a deeper understanding, an understanding, established by other methods at the teacher's disposal.

In the formation of the axiological component of the communicative competence of future teachers sometimes there is a need for a convincing influence, not only in the right direction, but also in the reverse direction. It is very important to draw the reader's attention to the shortcomings in the use of this or that means of communication, to focus his attention on the purpose of communication and the way to achieve it.

Another method of pedagogical influence is the method of trust (belief). In the formation of the axiological component of communicative competence, the teacher uses this method to address the feelings, experiences, consciousness of students in order to form a valuable attitude to communicative motives, goals communication in pedagogical college students. Confidence (belief) can appear as proof, persuasion, or a combination of both. If a teacher needs to convince a student of the validity of a rule, then he or she creates a logically flawless chain of arguments to prove it. If the teacher is faced with the task of forming a valuable relationship to the communication activity or interaction participants (interlocutors), then it is necessary to address the feelings of the student. Then trust (belief) emerges as a fertilizer. Often the teacher appeals to both the mind and the senses of the student at the same time.

Another method of trust is example, example. The following types of patterns are used in pedagogical practice: positive, negative, positive, indirect and figurative.

The persuasive power of the sample method depends on the extent to which a trusting relationship is formed between the students of the pedagogical college and the teacher who uses this method, giving an example.

Suggestion or persuasion is a method of verbal and nonverbal emotional embellishment of the audience. The purpose of persuasion is to create a certain emotional state in students. This method is also used to motivate action. It is impossible to overestimate the possibilities of the persuasion method. Along with the method of persuasion, it is necessary to use other methods of influence, for example, to strengthen the argument, the proof. Otherwise, the use of persuasion can provoke a backlash in students a stubborn attitude in any case [ 9,72 p].

Pedagogical coaching is a method of creating an environment (using conversation and goaloriented behavior) that helps to motivate college students in communicative activities, to form and 
CURRENT RESEARCH JOURNAL OF PEDAGOGICS 2(6): 141-151, June

2021 DOI: https://doi.org/10.37547/pedagogics-crjp-02-06-27

ISSN 2767-3278

(C)2021 Master Journals

\section{Crossref dof 81 Google}

Accepted 25th June, 2021 \& Published 30 ${ }^{\text {th }}$ June, 2021

achieve communication goals to the extent that this process is satisfying. The purpose of pedagogical coaching is to gather students 'future opportunities and successes $[10,56 \mathrm{p}]$.

The use of methods of organizing the communicative activities of students of pedagogical colleges should be carefully planned by the teacher. The choice of this or that method is determined by the purpose, content, form of organization of the educational process, the structure of communicative competence and the formation of the necessary structural organizers. In this case, the selection and application of the listed methods is effective in compliance with the didactic conditions - the choice of methods of formation from the position of ensuring the communicative activity of students as a basis for ensuring the subjective position of pedagogical college students in the educational process [11].

These conditions determine the position and role of future teachers in communicative activity, and the conditions of communicative activity determine the method of communicative activity as a basis for ensuring the subjective position of the student in the educational process: monologue, dialogue, polylogue, telephone conversation and others.

The specificity of the role of future teachers in communicative activity leads to the justification of the classification of the means of its formation. The classification of means of formation of communicative competence of students of pedagogical college is based on their functions in communicative activity. The following conditions should be taken into account when choosing the means of formation of communicative competence - the use of means of formation of communicative competence should be based on ensuring their correlation with the function of students in communicative activity (means of motivation in communication, means of communication - means of communication).

Table 1. Correlation of methods of communication and methods of formation of communicative behavior of students of pedagogical college.

Table 1

\begin{tabular}{|l|l|}
\hline \multicolumn{1}{|c|}{$\begin{array}{c}\text { Communication } \\
\text { method }\end{array}$} & \multicolumn{1}{c|}{$\begin{array}{c}\text { The method of forming } \\
\text { communicative action }\end{array}$} \\
\hline Monologue & Student story \\
\hline Polilog & $\begin{array}{c}\text { Debate,dispute, democratic dialogue, } \\
\text { heuristic dialogue, cocrates, }\end{array}$ \\
\hline Dialog & $\begin{array}{c}\text { Conversations: classic, socratic } \\
\text { democratic }\end{array}$ \\
\hline Message & Presentation \\
\hline Phone conversation & Plot-role game \\
\hline Discussion & Dispute, debate \\
\hline Telegram SMS & Didactik game \\
\hline Reflection & Conversation, debate dispute \\
\hline Exit & Presentation \\
\hline Argumentation & Proof \\
\hline Negation & Dispute, didactik game, plot-role game \\
\hline
\end{tabular}




\begin{tabular}{|c|c|}
\hline Question & $\begin{array}{l}\text { Conversations: heuristic, } \\
\text { democratic, plot-role play, dispute }\end{array}$ \\
\hline Letter & Didactic game, plat-role game \\
\hline
\end{tabular}

Table 2. Functional correlation of communication methods and means of formation of communicative competence of pedagogical college students.

Table 2

\begin{tabular}{|c|c|c|c|}
\hline $\begin{array}{c}\text { Functions in } \\
\text { communication }\end{array}$ & $\begin{array}{c}\text { Means of } \\
\text { communication } \\
\text { motivation }\end{array}$ & $\begin{array}{c}\text { Intermediaries in } \\
\text { communication }\end{array}$ & $\begin{array}{c}\text { Means of providing } \\
\text { meaningful } \\
\text { communication- } \\
\text { sources of } \\
\text { information }\end{array}$ \\
\hline $\begin{array}{c}\text { Means of forming } \\
\text { communicative } \\
\text { competence }\end{array}$ & $\begin{array}{c}\text { Works of art, visual } \\
\text { aids, speeches of } \\
\text { speakers, natural } \\
\text { objects }\end{array}$ & $\begin{array}{c}\text { Mobile } \\
\text { communications, social } \\
\text { networks, PC-as are } \\
\text { intermediary, } \\
\text { dictaphone, microphone }\end{array}$ & $\begin{array}{c}\text { reference books, PC- } \\
\text { as a sovrce of } \\
\text { information,the media }\end{array}$ \\
\hline
\end{tabular}

As shown in our work, the existence of goals, objectives and compliance with the listed conditions of formation of communicative competence of students of pedagogical college determines the optimal choice of content, form, methods, tools and ensures the achievement of the planned result. 
The structure of the development of communicative corapetence of future teachers

Tasks-these tasks are determined by the structure of communicative competencies

Forming knowledge about the types and methods of communication.

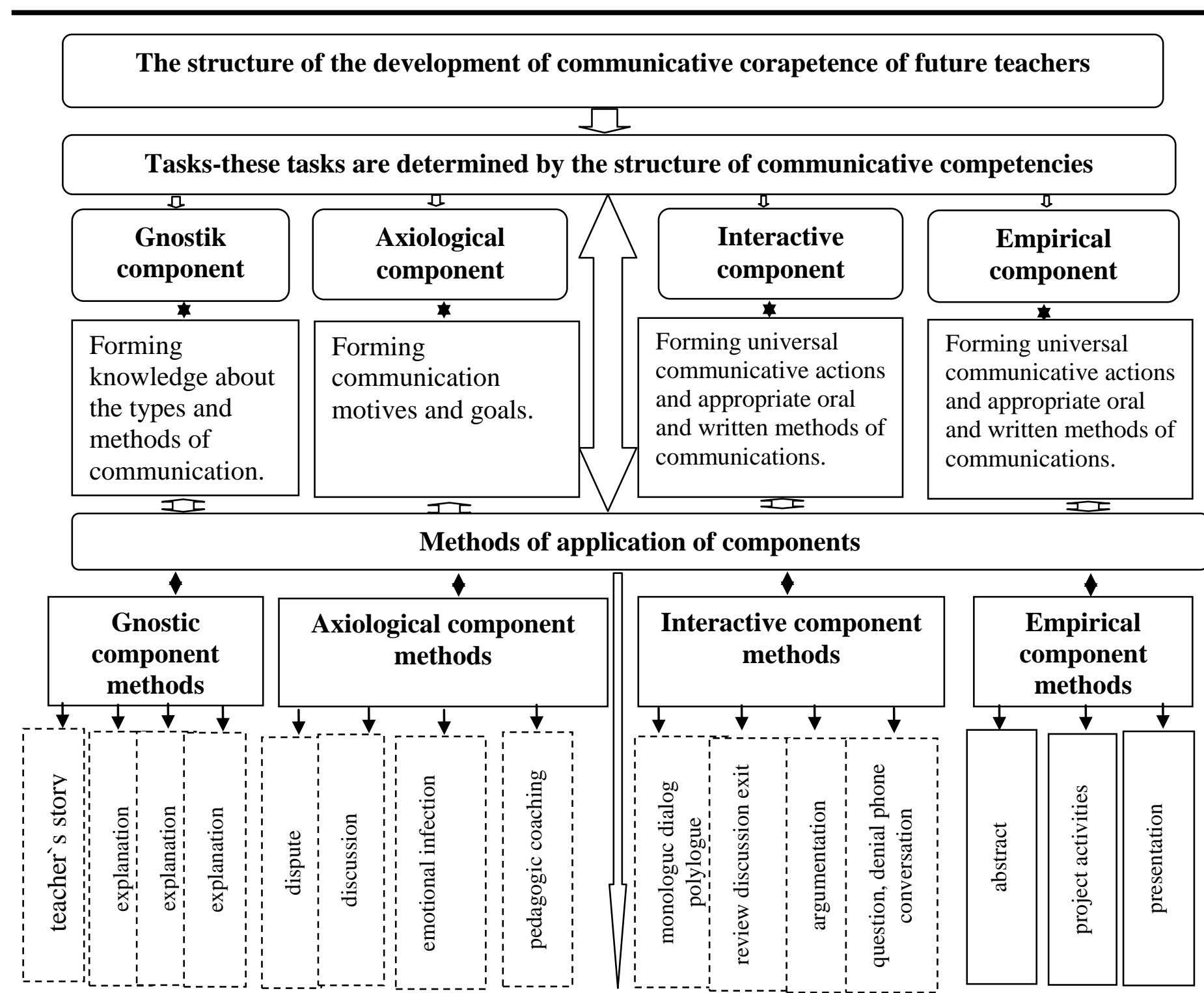

Forming communication motives and goals.

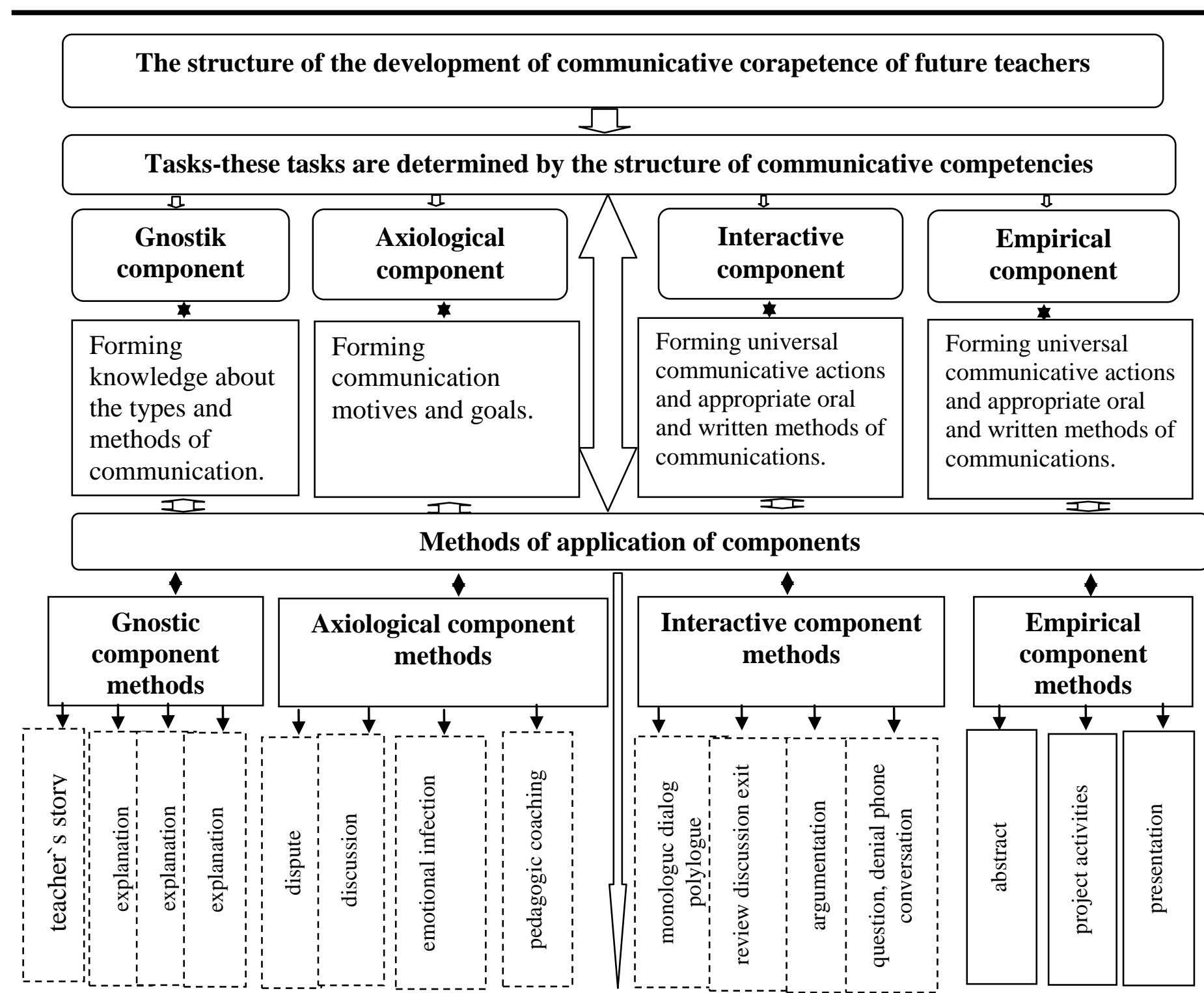

Forming universal communicative actions and appropriate oral and written methods of communications.
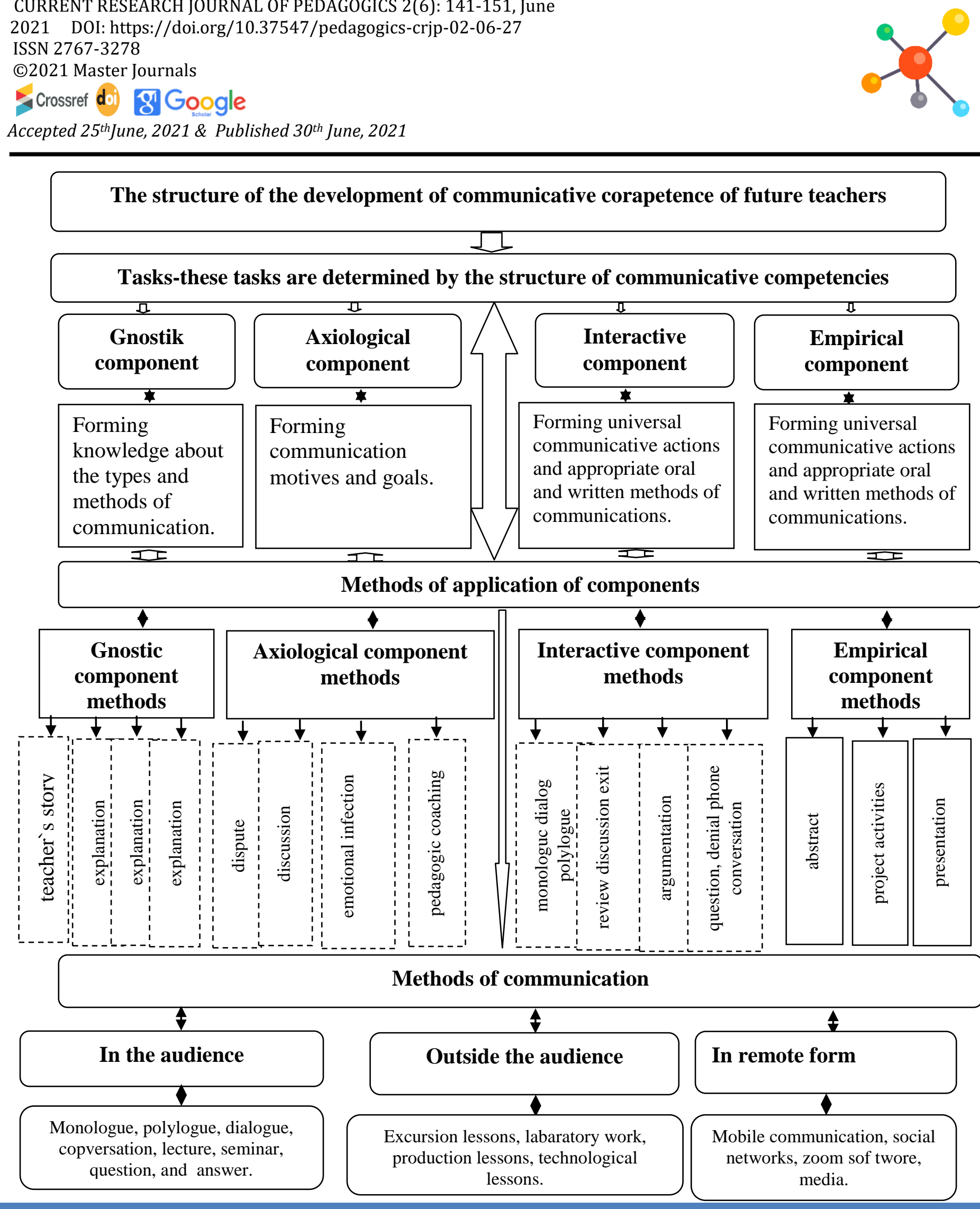
CURRENT RESEARCH JOURNAL OF PEDAGOGICS 2(6): 141-151, June

2021 DOI: https://doi.org/10.37547/pedagogics-crjp-02-06-27

ISSN 2767-3278

(C)2021 Master Journals

\section{Crossref dof 81 Google}

Accepted 25th June, 2021 \& Published 30 ${ }^{\text {th }}$ June, 2021

Figure 1. The structure of the development of communicative competence in of future teachers.

From the components of communicative competence in the given structure we can observe the following aspects which should be formed in pedagogical college students.

\section{Cognitive component:}

methodological basis, normative base and content of professional education;

innovative processes in teaching in the pedagogical college;

features of a competent approach to teaching sciences;

determine the structure of student competence;

nomenclature of basic competencies;

main directions of modernization of vocational education;

to know the technological aspects of the implementation of a competent approach in pedagogical colleges and the principles of selection of the content of the given disciplines.

\section{Axiological component:}

- Recognition of the feasibility and appropriateness of the application of students of pedagogical colleges;

- Positive attitude to the communicative activity of students of pedagogical colleges.

\section{Interactive component:}

technologies for the formation of students' knowledge of the content and norms of communicative activity;

technologies for forming a positive attitude in students to communicative activities;

technologies for the formation of communicative universal learning movements in students;

application of technologies to form a positive experience of communicative activity in students.

\section{Empirical component:}

- technological map of the lesson aimed at the formation of communicative competence of students of pedagogical college;

- technological map of extracurricular activities aimed at the formation of communicative competence of students of pedagogical colleges;

- monitoring the process of formation of communicative competence of students and designing diagnostic maps of the organizers of communicative competence;

- making KIMs (?) to assess those who form communicative competence.

The presence of motivation of students of pedagogical college to communicative activity is a sign of completion of the diagnostic-corrective stage of formation of communicative competence. Motivation, in turn, is the basis for setting goals in students 'communicative activities.

It follows from the above that the motives of communicative activity of future teachers are directly related to their needs. The need for new impressions creates pedagogical motivation for communication college students, the need for active action - the business motivation of communication, and the need for support and recognition is the basis for the emergence of personal motives for communication.

\section{Conclusion}

Thus, the identification of the leading motives of communicative activity of future teachers allows to move to the second - communicative-activity 
CURRENT RESEARCH JOURNAL OF PEDAGOGICS 2(6): 141-151, June

2021 DOI: https://doi.org/10.37547/pedagogics-crjp-02-06-27

ISSN 2767-3278

(C)2021 Master Journals

\section{Crossref do) 81 Google}

Accepted 25th June, 2021 \& Published 30 ${ }^{\text {th }}$ June, 2021

stage of formation of communicative competence. The communicative-activity stage involves the direct involvement of future teachers in communicative activities. The presence of motives, as a result, determines the subject of formation of a valuable attitude of the student to the communicative activity - the communicative goal setting. The need for goal setting is explained by the importance of future teachers taking a subjective position in communicative activities.

\section{ReFERENCES}

1. S.G.Batyreva, Communicative goal-setting as the basis for the typologization of tasks for the formation of communicative universal educational actions. Standards and monitoring in education. No. 4, 2013; from. 46-52.

2. I.T. Aliev, Professional competence of the teacher. Problems and prospects of development of professional and pedagogical competence of teachers in continuous education: Materials of the Republican scientific-practical conference. - Tashkent. TDPU named after Nizami, 2013. $-55 \mathrm{p}$

3. S. G. Batyreva, Typical tasks for the formation of universal educational actions. Literary reading. Grade 4: a guide for students of educational institutions. - $\mathrm{M}$.: Education, 2014 .- 61 p. (We work according to new standards).

4. Batyreva S.G. To the question of the conditions for the formation of communicative ECDs, ed. OV Zhukovoy Pedagogical achievements of teacherswinners of PNPO and the best teachers of educational organizations - the potential for the development of a new school in the Moscow region: materials of the VIII Regional Scientific and Practical
Conference. - M .: GBOU VPO MO ASOU, 2015 -- S. 275-279.

5. R. Sh. Moshnina, Competence-based approach as a methodological basis for the activities of pedagogical communities in the implementation of the Federal State Educational Standard. Professional pedagogical communities as a strategic resource for improving the quality of education: materials of the international scientific and practical conference. - $\mathrm{M}$.: Akademkniga Textbook, 2013 --- S. 34-37.

6. S.G. Batyreva, Moshnina, R. Sh. Assessment of the effectiveness of the organization of extracurricular activities of primary schoolchildren. Primary education. - 2013. - No. 5 (58). - S. 23-29.

7. Psychological and pedagogical dictionary. Compiled by Rapatsevich E. S. - Minsk: "We will lie. Word ", 2006. - 404 p.

8. S.G. Batyreva, Model of the formation of the communicative competence of junior schoolchildren in the educational process. Bulletin of the Volgograd State Pedagogical University. - 2015. - No. 6. - p.28-31.

9. Pedagogical encyclopedic dictionary. Ed. B.M.Bim-Bad. - M .: Great Russian Encyclopedia, 2002 -- 284 p.

10. R.Sh. Moshnina, Scientific and methodological foundations of preparing students for teaching alternative courses in the natural science cycle in elementary school:Diss. Cand. ped. sciences. - M .: RAO IOSO, $1995.72 \mathrm{p}$.

11. I.T.Unt, Individualization and differentiation of education. - $\mathrm{M}$.: pedagogy, 1990 -- $56 \mathrm{p}$.

12. S.G. Batyreva, Communicative competence as a result of primary general education. Academic Bulletin. - 2015. - No. 3. - S. 66 - 
CURRENT RESEARCH JOURNAL OF PEDAGOGICS 2(6): 141-151, June

2021 DOI: https://doi.org/10.37547/pedagogics-crjp-02-06-27

ISSN 2767-3278

(C)2021 Master Journals

Crossref dof 81 Google

Accepted 25th June, 2021 \& Published 30 $0^{\text {th }}$ June, 2021

75.

13. O.E Azizov., The role of communication and speech in the formation and development of communicative competencies of students of the Pedagogical College. Scientific-methodical, practical, educational journal of vocational education. 2021, №2 